\title{
VERTICAL INTERACTION BETWEEN A DRIVING WHEELSET AND TRACK IN THE PRESENCE OF THE ROLLING SURFACES HARMONIC IRREGULARITIES
}

Traian Mazilu, Prof. PhD. Eng. University Politehnica of Bucharest, e-mail: trmazilu@yahoo.com

Ionuţ Radu Răcănel, Assoc. Prof. PhD. Eng. Technical University of Civil Engineering Bucharest, e-mail: ionut_racanel@yahoo.com

Marius Alin Gheți, PhD student, Doctoral School of Transports, University Politehnica of Bucharest, e-mail: gheti_marius@yahoo.co.uk

\section{Rezumat}

Osia motoare este utilizată în tracțiunea feroviară (locomotive, trenuri electrice, tramvaie etc) pentru a susține o parte din greutatea masei suspendate și pentru a tracta și frâna vehiculul. Dinamica sistemului osie motoare - cale de rulare este o problemă foarte importantă în ingineria vehiculelor feroviare, iar această lucrare tratează proprietățile de bază ale funcțiilor de răspuns în frecvență care descriu regimul dinamic în prezența neregularităților de formă armonică ale suprafețelor de rulare. Pentru aceasta, s-a adoptat un model simplu al sisyemului osie motoare-cale de rulare al cărui domeniu de aplicare este limitat la 6-700 Hz. Modelul osiei motoare constă dintr-o grindă Euler-Bernouli de secțiune constată, liberă la capete, de care sunt atașate trei corpuri rigide reprezentând osia, cele două roți și coroana dințată; modelul prezintă asimetrie inerțială. Modelul căii este alcătuit din două grinzi Euler-Bernoulli de lungime infinită, independente, fiecare fiind așezată pe propria fundaţie alcătuită din două straturi elastice pentru a modela plăcuțele de șină și balastul și un strat inerțial intermediar pentru traverse. Pentru simplitate, s-a aplicat modelul neregularității mobile pentru a simula interacțiunea dintre roți și șine. Simulările numerice arată că sistemul osie motoare-cale de rulare are trei frecvențe de rezonanță, toate situate în domeniul de frecvență al undelor evanescente ale șinelor. Au fost calculate funcțiile de răspuns în frecvență pentru cuplul roată-șină. S-a pus în evidență influența asimetriei inerțiale a osiei motoare și a defazajului dintre neregularitățile suprafețelor de rulare cu ajutorul funcțiilor de răspuns în frecvență ale forței de contact dintre roți și șine.

Cuvinte cheie: osie motoare, cale de rulare, receptanță, forță de contact, neregularitate armonică, funcția de răspuns în frecvență

\section{Abstract}

The driving wheelset is used in railway traction (locomotives, electric trains, trams, etc.) to support part of the weight of the suspended mass and to drive and brake the vehicle. The dynamics of the driving wheelset/track system is a very important issue in the railway 
engineering, and this paper is focused on basic features of the frequency response functions which describe the dynamic behavior in the presence of the rolling surfaces harmonic irregularities. To this end, a simple model of the driving wheelset/track system with the range of application limited up to 6-700 $\mathrm{Hz}$ is adopted. The driving wheelset model consists of a free-free uniform Euler-Bernoulli beam with three attached rigid bodies, representing the axle, the two wheels and the gear; the distinct feature of this model is the inertial asymmetry. Two independent infinite uniform Euler-Bernoulli beams, each on its foundation including two elastic layers for rail pad and ballast and an intermediate inertial layer for sleepers represent the track model. For simplicity, the moving irregularity model is applied to simulate the interaction between wheels and rails. Numerical simulations show that the driving wheelset/track system has three resonance frequencies, all situated in the frequency range of the evanescent waves in rails. FRF of the driving wheelset/track system have been calculated for left and right wheel/rail pair. The influence of the asymmetric inertia of the driving wheelset and the out of phase between the rolling surface irregularities are evaluated in terms of frequency response functions of the wheel/rail contact force.

Keywords: driving wheelset, track, receptance, contact force, harmonic irregularity, frequency response function

\section{INTRODUCTION}

Wheelset dynamics is important for some technical reasons: traction, braking, ride quality, rolling gear and track components fatigue, noise and wear of the rolling surfaces [1-3].

When a driving wheelset is rolling on track, the interaction phenomenon between these can be studied considering separately the normal and tangential problems. First issue occupies with the normal contact forces and the second one, with the friction forces between wheels and rails.

In many researches, the wheelset is treated as a symmetric structure or the driving wheelset dynamics is reduced to the one of single wheel, disregarding the inertial asymmetry of the wheelset [4-5]. However, the steady-state interaction between driving wheelset and track, presumed periodic structure, has been approached in ref. [6].

In this paper, authors intend to bring new findings regarding the influence of the inertial asymmetry on the frequency response functions of a driving wheelset/track system. To this aim, the entire wheelset structure is considered (wheels and gear), while the track model is reduced to two infinite EulerBernoulli beams on elastic foundation of three layers (two elastic layer and an inertial one), modeling the rails, rail-pad, sleepers and ballast bed. The main characteristics of the system are identified and the impact of the inertial 
asymmetry of the wheelset upon the driving wheelset/rails dynamics is pointed out.

\section{MECHANICAL MODEL}

The case is considered of a driving wheelset interacting with a track in the presence of the rolling surfaces irregularities as shown in Figure 1. The driving wheelset is modelled using a continuous-discrete model, and the track is considered as two independent infinite continuous systems, neglecting the rails coupling via sleepers. The driving wheelset/track interaction in the presence of the rolling surfaces irregularities is approached considering two moving irregularities between the stationary driving wheelset and rails.
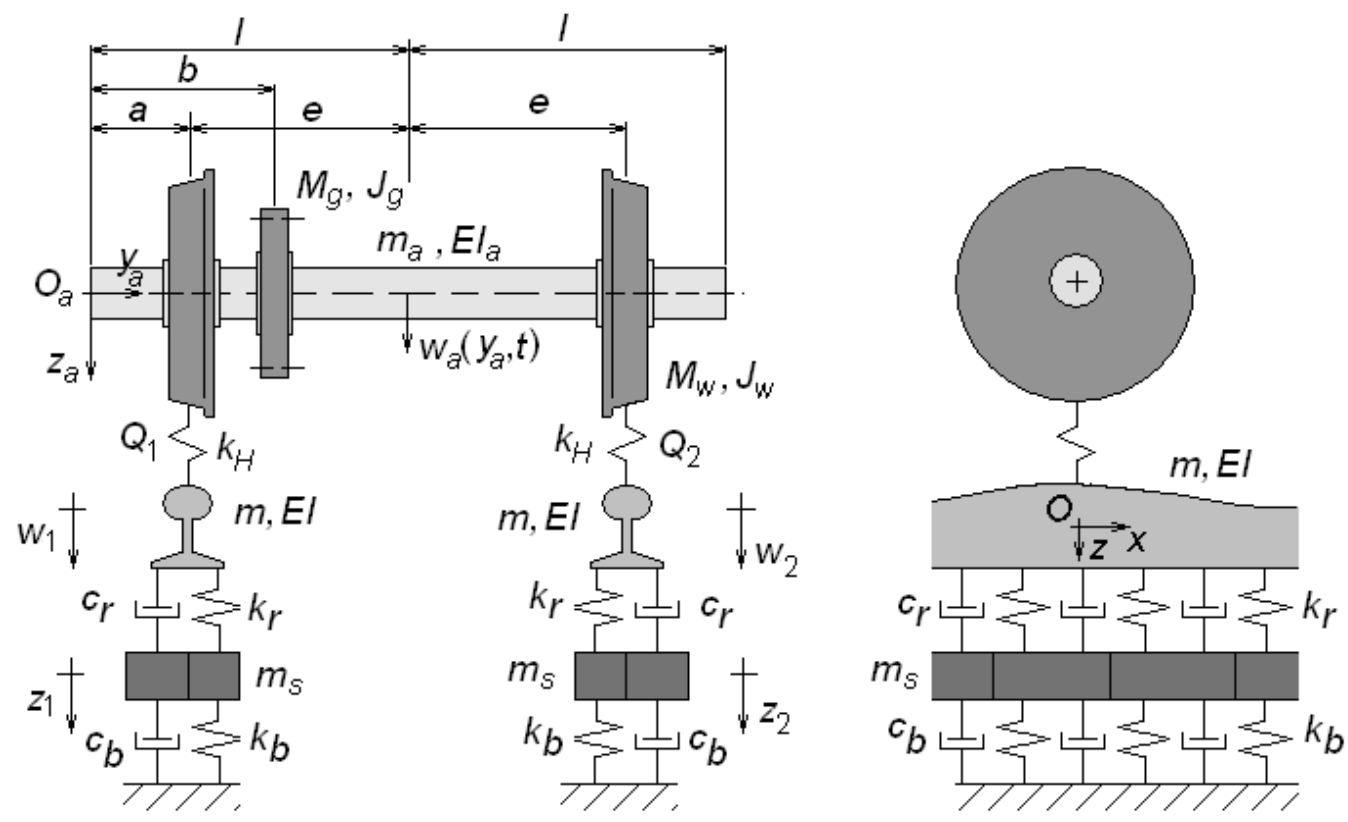

Figure 1. Driving wheelset-track model.

The driving wheelset model consists of a uniform free-free EulerBernoulli beam with tree rigid bodies attached, representing the axle, the two wheels and the gear. Parameters for the driven wheelset model are as follows: $2 l$ axle length, $E I_{a}$ bending stiffness, where $E$ is Young's modulus and $I_{a}$ is the moment of inertia of the cross-section, $m_{a}$ axle mass per length unit, $M_{w}$ mass and $J_{w}$ mass moment of inertia for wheels and $M_{g}$ mass and $J_{g}$ mass moment of inertia for driven gear. The wheels are located at distance $a$ from the axle ends, 
while the gear is at distance $b$ from the left end. Distance between wheels is noted $2 e$.

The motion of the driving wheelset/track system is viewed as a perturbation around the stationary position given by the stationary loads on wheels, but not displayed here.

The driving wheelset motion is related to the fixed reference system $O_{a} y_{a} z_{a}$ and the axle deflection, $w_{a}\left(y_{a}, t\right)$, satisfies the equation of motion

$$
\begin{aligned}
& E I_{a} \frac{\partial^{4} w_{a}\left(y_{a}, t\right)}{\partial y_{a}^{4}}+m_{a} \frac{\partial^{2} w_{a}\left(y_{a}, t\right)}{\partial t^{2}}+ \\
& M_{w}\left[\frac{\partial^{2} w_{a}(a, t)}{\partial t^{2}} \delta\left(y_{a}-a\right)+\frac{\partial^{2} w_{a}(l-a, t)}{\partial t^{2}} \delta\left(y_{a}-l+a\right)\right]- \\
& J_{w}\left[\frac{\partial^{3} w_{a}(a, t)}{\partial y_{a} \partial t^{2}} \delta^{\prime}\left(y_{a}-a\right)+\frac{\partial^{3} w_{a}(l-a, t)}{\partial y_{a} \partial t^{2}} \delta^{\prime}\left(y_{a}-l+a\right)\right]+ \\
& M_{g} \frac{\partial^{2} w_{a}(b, t)}{\partial t^{2}} \delta\left(y_{a}-b\right)-J_{g} \frac{\partial^{3} w_{a}(b, t)}{\partial x \partial t^{2}} \delta^{\prime}\left(y_{a}-b\right)= \\
& -Q_{1}(t) \delta\left(y_{a}-a\right)-Q_{2}(t) \delta\left(y_{a}-l+a\right),
\end{aligned}
$$

where $Q_{1,2}(t)$ are the wheel/rail contact forces (only dynamic component); these forces are positives on the rail.

Applying the modal analysis method, the axle deflection can be written

$$
w_{a}\left(y_{a}, t\right)=w_{a o}(t)+\left(y_{a}-l / 2\right) \theta_{a o}(t)+\sum_{n=1}^{\infty} Y_{n}\left(y_{a}\right) T_{n}(t),
$$

where $w_{a o}(t)$ and $\theta_{a o}(t)$ are the time coordinates for the rigid vibration modes of the wheelset - bounce and roll, and $T_{n}(t)$ and $Y_{n}\left(y_{a}\right)$ are the time coordinate and the eigenfunction of the $n^{\text {th }}$ elastic vibration mode.

Retaining the rigid vibration modes and the first two elastic vibration modes, the wheelset motion can be described by the following matrix equation

$$
\mathbf{M} \ddot{\mathbf{q}}+\mathbf{K q}=\mathbf{Q},
$$


where $\mathbf{q}$ is the column vector of the four coordinates of times $\left(w_{a o}, \theta_{a o}, T_{1}\right.$ and $T_{2}$ ), $\mathbf{M}$ and $\mathbf{K}$ are the inertia and stiffness $4 \times 4$ matrix and $\mathbf{Q}-$ the column vector of the four modal forces.

Considering the steady-state harmonic behavior, the driving wheelset response can be given by the displacements of the axle at the two wheels

$$
\begin{aligned}
& \bar{w}_{a 1}=-\left(\bar{\alpha}_{11} \bar{Q}_{1}+\bar{\alpha}_{12} \bar{Q}_{2}\right) \\
& \bar{w}_{a 2}=-\left(\bar{\alpha}_{21} \bar{Q}_{1}+\bar{\alpha}_{22} \bar{Q}_{2}\right),
\end{aligned}
$$

where $\bar{\alpha}_{i j}$ with $i, j=1,2$ is the axle receptance at the $i$ wheel due to the unit harmonic force acting at the $j$ wheel, and $\bar{Q}_{1,2}$ is the harmonic force; $\bar{\alpha}_{i j}=\bar{\alpha}_{j i}$ due to the Maxwell-Betty principle.

The track model has two identic infinite systems, each of them consisting of a continuous Euler-Bernoulli beam supported on a foundation with two elastic layers with an intermediate inertial layer. The Euler-Bernoulli beam models the rail, the elastic layers introduce the viscoelastic features of the rail pad and ballast, while the inertial layer is for sleepers. In this track model, the influence of the equidistant supports (sleepers) is disregarded, limiting the frequency range of the model up to 6-700 $\mathrm{Hz}$ [7].

The parameters for the track model are: $E I$ - the bending stiffness of the rail, $m$ - the rail mass per unit length, $k_{r}$ - the railpad stiffness per unit length, $c_{r}$ - the damping constant per unit length of the railpad, $m_{s}$ - the sleeper mass per unit length, $k_{b}$ - the ballast stiffness per unit length and $c_{b}$ - the damping constant per unit length of the ballast.

Considering the vertical displacements of the rails, $w_{1,2}(x, t)$, and the sleepers, $z_{1,2}(x, t)$, in respect to the reference frame $O x z$, the equations of motion are:

$$
\begin{aligned}
& E I \frac{\partial^{4} w_{1,2}(x, t)}{\partial x^{4}}+m \frac{\partial^{2} w_{1,2}(x, t)}{\partial t^{2}}+c_{r}\left(\frac{\partial w_{1,2}(x, t)}{\partial t}-\frac{\partial z_{1,2}(x, t)}{\partial t}\right)+ \\
& k_{r}\left[w_{1,2}(x, t)-z_{1,2}(x, t)\right]=Q_{1,2}(t) \delta(x) \\
& m_{s} \frac{\partial^{2} z_{1,2}(x, t)}{\partial t^{2}}+c_{r}\left(\frac{\partial z_{1,2}(x, t)}{\partial t}-\frac{\partial w_{1,2}(x, t)}{\partial t}\right)+c_{b} \frac{\partial z_{1,2}(x, t)}{\partial t}+ \\
& k_{r}\left[z_{1,2}(x, t)-w_{1,2}(x, t)\right]+k_{b} z_{1,2}=0 .
\end{aligned}
$$


For the steady-state harmonic behavior, the rails and sleeper displacements at the acting section $(x=0)$ are

$$
\bar{w}_{1,2}=\bar{\alpha}_{r} \bar{Q}_{1,2}
$$

where $\bar{\alpha}_{r}$ is the rail receptance calculated for the section of the unit harmonic force.

Wheel/rail contact forces can be calculated applying linearized Hertz's contact theory

$$
Q_{1,2}=k_{H}\left(w_{a 1,2}-w_{1,2}-r_{1,2}\right),
$$

or, for the harmonic steady-state behavior,

$$
\bar{Q}_{1,2}=k_{H}\left(\bar{w}_{a 1,2}-\bar{w}_{1,2}-\bar{r}_{1,2}\right),
$$

where $r_{1,2}$ are the rolling surfaces irregularities and $k_{H}$ stands for the Hertzian contact stiffness.

Inserting (4) and (6) in equation (8), it holds

$$
\begin{aligned}
& \left(\bar{\alpha}_{11}+\bar{\alpha}_{r}+\bar{\alpha}_{H}\right) \bar{Q}_{1}+\bar{\alpha}_{12} \bar{Q}_{2}=-\bar{r}_{1} \\
& \bar{\alpha}_{21} \bar{Q}_{1}+\left(\bar{\alpha}_{22}+\bar{\alpha}_{r}+\bar{\alpha}_{H}\right) \bar{Q}_{2}=-\bar{r}_{2},
\end{aligned}
$$

where $\bar{\alpha}_{H}=1 / k_{H}$ is the receptance of the wheel/rail contact.

Problem solution is as follows:

- contact forces

$$
\begin{aligned}
& \bar{Q}_{1}=\frac{-\bar{r}_{1}\left(\bar{\alpha}_{22}+\bar{\alpha}_{r}+\bar{\alpha}_{H}\right)+\bar{\alpha}_{12} \bar{r}_{2}}{\left(\bar{\alpha}_{11}+\bar{\alpha}_{r}+\bar{\alpha}_{H}\right)\left(\bar{\alpha}_{22}+\bar{\alpha}_{r}+\bar{\alpha}_{H}\right)-\bar{\alpha}_{12} \bar{\alpha}_{21}} \\
& \bar{Q}_{2}=\frac{-\bar{r}_{2}\left(\bar{\alpha}_{11}+\bar{\alpha}_{r}+\bar{\alpha}_{H}\right)+\bar{\alpha}_{21} \bar{r}_{1}}{\left(\bar{\alpha}_{11}+\bar{\alpha}_{r}+\bar{\alpha}_{H}\right)\left(\bar{\alpha}_{22}+\bar{\alpha}_{r}+\bar{\alpha}_{H}\right)-\bar{\alpha}_{12} \bar{\alpha}_{21}}
\end{aligned}
$$


- wheelset displacement at wheels

$$
\begin{aligned}
& \bar{w}_{a 1}=\frac{\left[\bar{\alpha}_{11}\left(\bar{\alpha}_{22}+\bar{\alpha}_{r}+\bar{\alpha}_{H}\right)-\bar{\alpha}_{12} \bar{\alpha}_{21}\right] \bar{r}_{1}+\bar{\alpha}_{12}\left(\bar{\alpha}_{r}+\bar{\alpha}_{H}\right) \bar{r}_{2}}{\left(\bar{\alpha}_{11}+\bar{\alpha}_{r}+\bar{\alpha}_{H}\right)\left(\bar{\alpha}_{22}+\bar{\alpha}_{r}+\bar{\alpha}_{H}\right)-\bar{\alpha}_{12} \bar{\alpha}_{21}} \\
& \bar{w}_{a 2}=\frac{\left[\bar{\alpha}_{22}\left(\bar{\alpha}_{11}+\bar{\alpha}_{r}+\bar{\alpha}_{H}\right)-\bar{\alpha}_{12} \bar{\alpha}_{21}\right] \bar{r}_{2}+\bar{\alpha}_{21}\left(\bar{\alpha}_{r}+\bar{\alpha}_{H}\right) \bar{r}_{1}}{\left(\bar{\alpha}_{11}+\bar{\alpha}_{r}+\bar{\alpha}_{H}\right)\left(\bar{\alpha}_{22}+\bar{\alpha}_{r}+\bar{\alpha}_{H}\right)-\bar{\alpha}_{12} \bar{\alpha}_{21}}
\end{aligned}
$$

- rails displacement

$$
\begin{aligned}
& \bar{w}_{1}=\bar{\alpha}_{r} \frac{-\bar{r}_{1}\left(\bar{\alpha}_{22}+\bar{\alpha}_{r}+\bar{\alpha}_{H}\right)+\bar{\alpha}_{12} \bar{r}_{2}}{\left(\bar{\alpha}_{11}+\bar{\alpha}_{r}+\bar{\alpha}_{H}\right)\left(\bar{\alpha}_{22}+\bar{\alpha}_{r}+\bar{\alpha}_{H}\right)-\bar{\alpha}_{12} \bar{\alpha}_{21}} \\
& \bar{w}_{2}=\bar{\alpha}_{r} \frac{-\bar{r}_{2}\left(\bar{\alpha}_{11}+\bar{\alpha}_{r}+\bar{\alpha}_{H}\right)+\bar{\alpha}_{21} \bar{r}_{1}}{\left(\bar{\alpha}_{11}+\bar{\alpha}_{r}+\bar{\alpha}_{H}\right)\left(\bar{\alpha}_{22}+\bar{\alpha}_{r}+\bar{\alpha}_{H}\right)-\bar{\alpha}_{12} \bar{\alpha}_{21}} .
\end{aligned}
$$

If there is no reason that the rolling surfaces irregularities to be of different magnitude, next, only the difference between their phases is considered.

\section{NUMERICAL APPLICATION}

In this section, results are obtained by using the above model for the wheelset of an electric 060 EA locomotive in service on CFR (Romanian Railway).

The model parameters for the wheelset and track are as follows: $m_{a}=$ $244,4 \mathrm{~kg} / \mathrm{m}, E=210 \mathrm{GPa}, I_{a}=7.7136 \quad 10^{-5} \mathrm{~m}^{4}, l=2.11 \mathrm{~m}, a=0,35 \mathrm{~m}, b=0.52$ $\mathrm{m}, e=0.75 \mathrm{~m}, M_{w}=500 \mathrm{~kg}, J_{w}=48.8 \mathrm{kgm}^{2}, M_{g}=350 \mathrm{~kg}, J_{g}=17.7 \mathrm{kgm}^{2}, m=$ $60 \mathrm{~kg} / \mathrm{m}, I=3.055 \quad 10^{-5} \mathrm{~m}^{4}, m_{s}=215 \mathrm{~kg} / \mathrm{m}, k_{r}=400 \mathrm{MN} / \mathrm{m}^{2}, c_{r}=61.97 \mathrm{kNs} / \mathrm{m}$, $k_{b}=70 \mathrm{MN} / \mathrm{m} 2, c_{b}=73.61 \mathrm{kNs} / \mathrm{m}, k_{H}=1.5 \mathrm{GN} / \mathrm{m}$.

Figure 2 displays the wheelset receptance calculated at the two wheels when the harmonic unit force acts on each wheel. The receptance at the left wheel $\left(\bar{\alpha}_{11}\right)$ is lower due to the presence of the gear near this wheel. The wheelset experiences resonance behavior at 89.4 and $191.3 \mathrm{~Hz}$. The left wheel receptance has antiresonance frequencies at 87.3 and $190 \mathrm{~Hz}$, and the right wheel receptance, at 88.0 and $185.3 \mathrm{~Hz}$. 
ROMANIAN JOURNAL

OF TRANSPORT INFRASTRUCTURE

Traian Mazilu, Ionuţ Radu Răcănel, Marius Alin Gheți,

Vertical interaction between a driving wheelset and track in the presence of the rolling surfaces harmonic irregularities

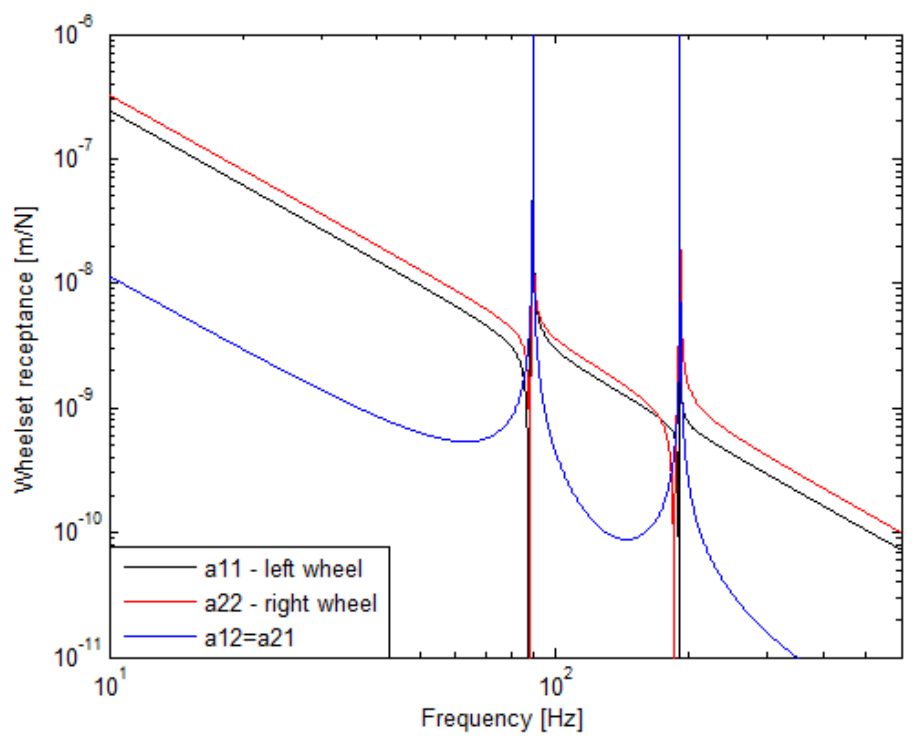

Figure 2. Wheelset receptance.

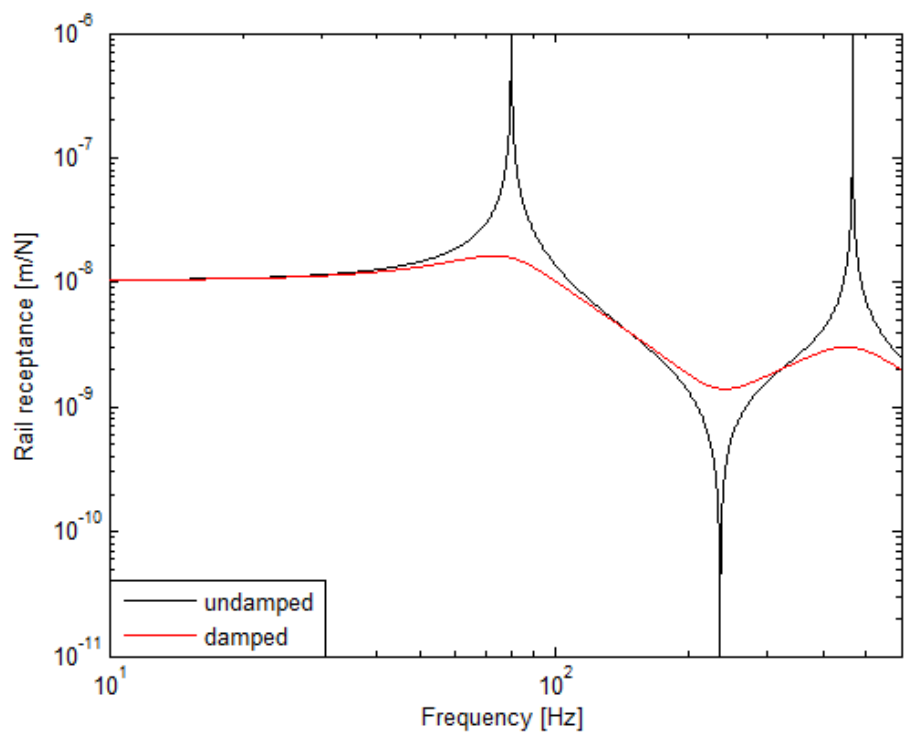

Figure 3. Rail receptance.

Figure 3 shows the rail receptance calculated for both undamped and damped case. Rail receptance is dominated by two resonance frequencies. The lowest frequency is at $80.0 \mathrm{~Hz}$, while the highest one has the value of $466.7 \mathrm{~Hz}$. Further, the rail receptance exhibits an antiresonance frequency at $235.3 \mathrm{~Hz}$. Should be underlined that at the first resonance, the rail and sleepers are in phase, and at the second resonance, the rail and sleepers are out of phase. 
On the one hand, when the frequency is smaller than the first resonance frequency or it is situated between the antiresonance frequency and the second resonance frequency, the rail exhibits evanescent waves. In this case, the rail receptance has only real positive values. On the other hand, the rail experiences propagating waves, when the frequency of the harmonic force is between the first resonance frequency and the frequency of antiresonance or it is higher than the second resonance frequency. This time, the rail receptance takes complex values. The damping limits the receptance at the resonance frequencies but increases the receptance values in the vicinity of the antiresonance frequency.
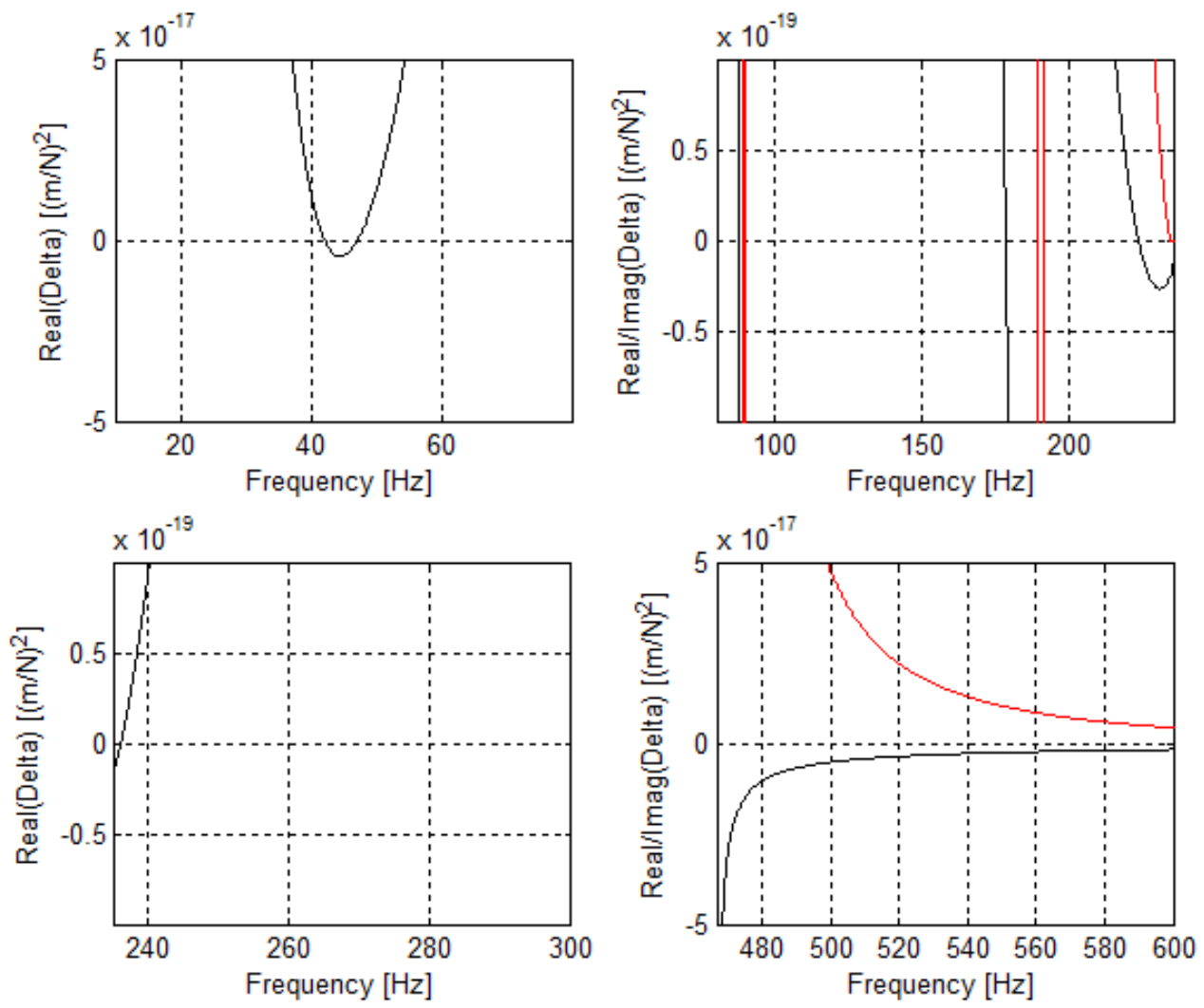

Figure 4. Illustrative to searching for natural frequencies:

black line $-\operatorname{Re} \Delta ;$ red line $-\operatorname{Im} \Delta$.

The features of the wheelset/track interaction are depending on the wheelset and rail receptances. Searching for resonance phenomenon in the wheelset/track system, the characteristic equation must be extracted from Eqs. (9)

$$
\Delta=\left(\bar{\alpha}_{11}+\bar{\alpha}_{r}+\bar{\alpha}_{H}\right)\left(\bar{\alpha}_{22}+\bar{\alpha}_{r}+\bar{\alpha}_{H}\right)-\bar{\alpha}_{12} \bar{\alpha}_{21}=0 .
$$


Figure 4 shows the real and imaginary part of $\Delta$ depending on the frequency ranges of the evanescent and propagating waves in the rail. The frequency interval between 300 and $466.7 \mathrm{~Hz}$ is ignored of obvious reason, the real part of $\Delta$ does not cross the zero line. When the frequency range of the evanescent wave is considered, the imaginary part of $\Delta$ is missing. The following resonance frequencies result: 42.1 and $47.2 \mathrm{~Hz}$ corresponding to bounce and roll of the wheelset on track, and $236.2 \mathrm{~Hz}$, respectively.

Figure 5 and 6 presents the frequency response function (FRF) for the two wheels and rails when the two rolling surface irregularities are in phase. The three frequencies of resonance calculated above can be identified. In general, the FRF of the left wheel is lower than the FRF of the right wheel, except the frequency range under the first resonance frequency. At low frequency, smaller than the first resonance frequency, the wheel displacement is higher than rail's one due to the high wheelset receptance. Otherwise, the rail vibration is more intense than the wheel's one.

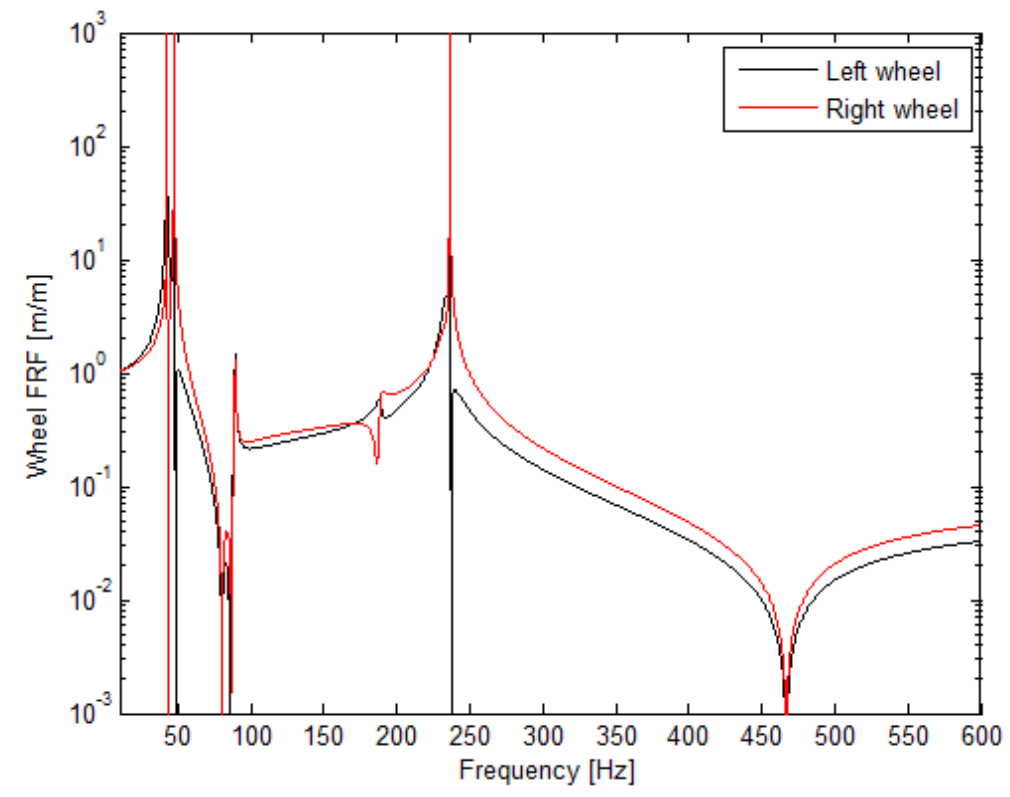

Figure 5. Wheel FRF.

Some correlations between the FRF and the receptances of the wheelset and rail can be pointed out. For instance, when the rail exhibits resonance behavior, the wheel FRF accuse an antiresonance (at 80 and $466 \mathrm{~Hz}$, see Fig. 4). Also, the wheel FRF takes local minimum value in the vicinity of an 
ROMANIAN JOURNAL

OF TRANSPORT INFRASTRUCTURE

Traian Mazilu, Ionuţ Radu Răcănel, Marius Alin Gheți,

Vertical interaction between a driving wheelset and track in the presence of the rolling surfaces harmonic irregularities

antiresonance of the wheel, and local maximum value in the vicinity of a wheelset resonance frequency. The latest correlations can be viewed in Figure 7.

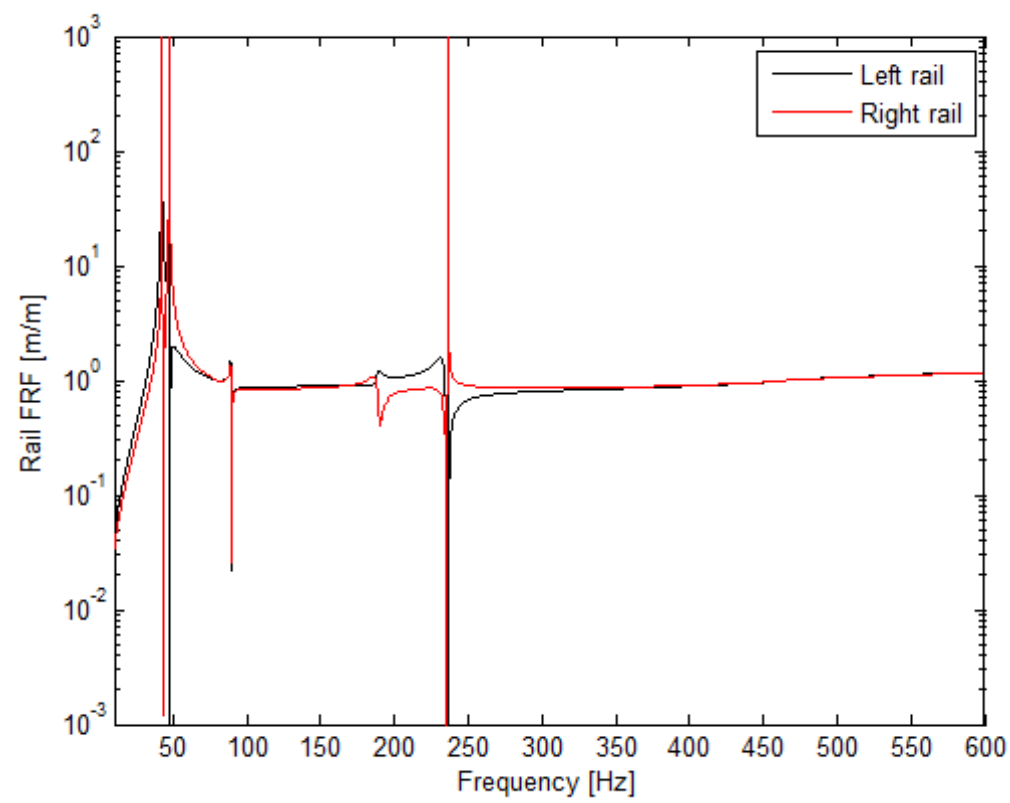

Figure 6. Rail FRF.

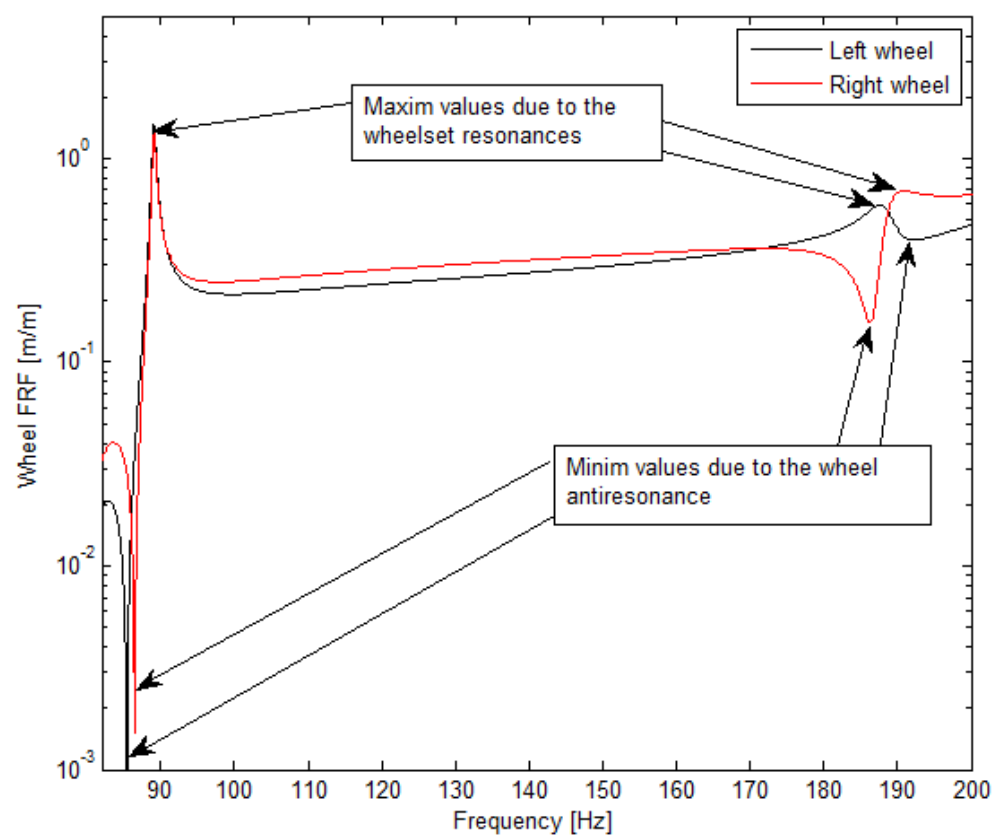

Figure 7. Rail FRF. 


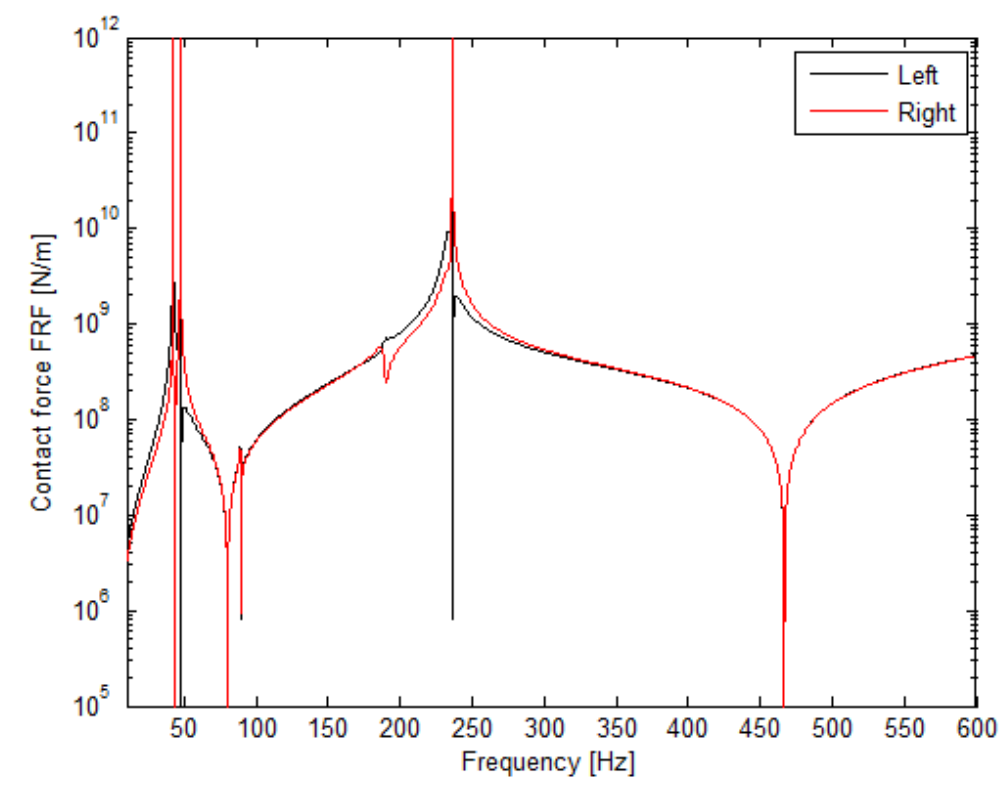

Figure 8. FRF of the contact force (undamped track).

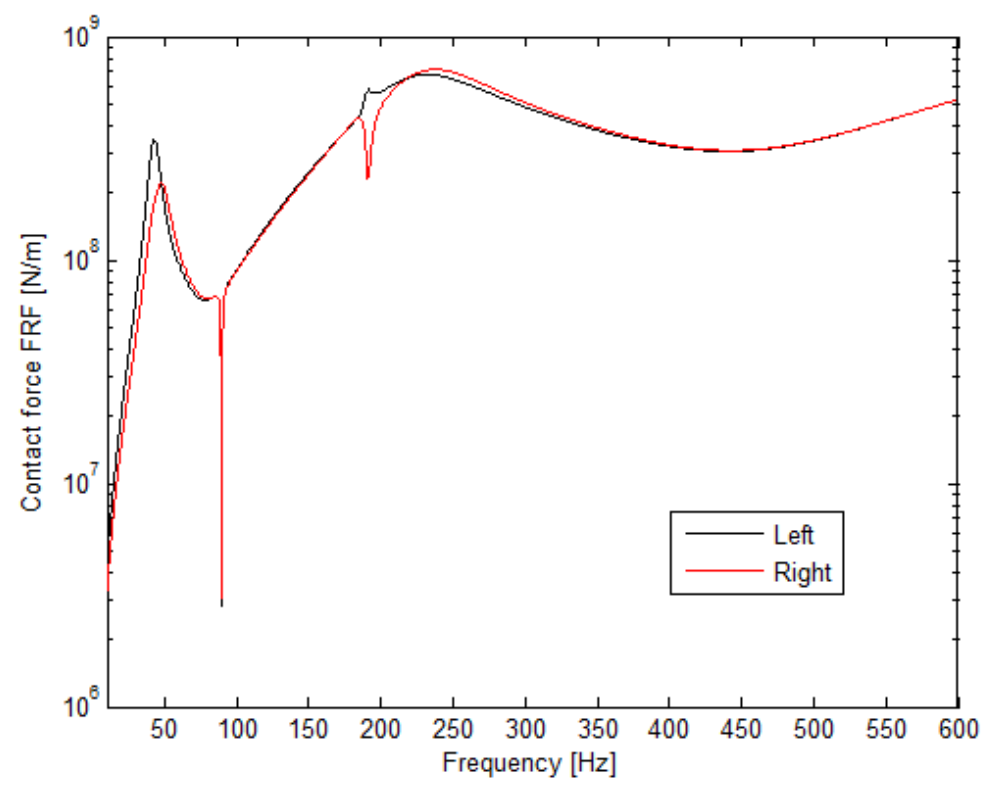

Figure 9. FRF of the contact force (damped track).

Figure 8 displayes the FRF of the two contact forces for the undamped case and Figure 9 shows the same functions when the track model is damped. On the one hand, the contact force has local maximum values at the frequencies of resonance of the wheelset/track system.

On the other hand, both contact forces exhibit local minimum values at 80 $\mathrm{Hz}$ (rail resonance), $89.3 \mathrm{~Hz}$ (wheelset resonance), $192 \mathrm{~Hz}$ - the left wheel, and 
$190 \mathrm{~Hz}$ - the right wheel, corresponding to the wheelset resonance, and at 466 $\mathrm{Hz}$ due to the second rail resonance. When the track model is damped, the resonance peaks and the antiresonance deeps are attenuated or even vanished. For instance, the two peaks and deeps from the wheelset/track bounce and roll disappear and, in their place, a single blunt tip appears. Similar effects can be noticed at the local minimum values from $80 \mathrm{~Hz}$, which disappears, $89.3 \mathrm{~Hz}$ or $466 \mathrm{~Hz}$ or at the third resonance frequency $(236 \mathrm{~Hz})$.
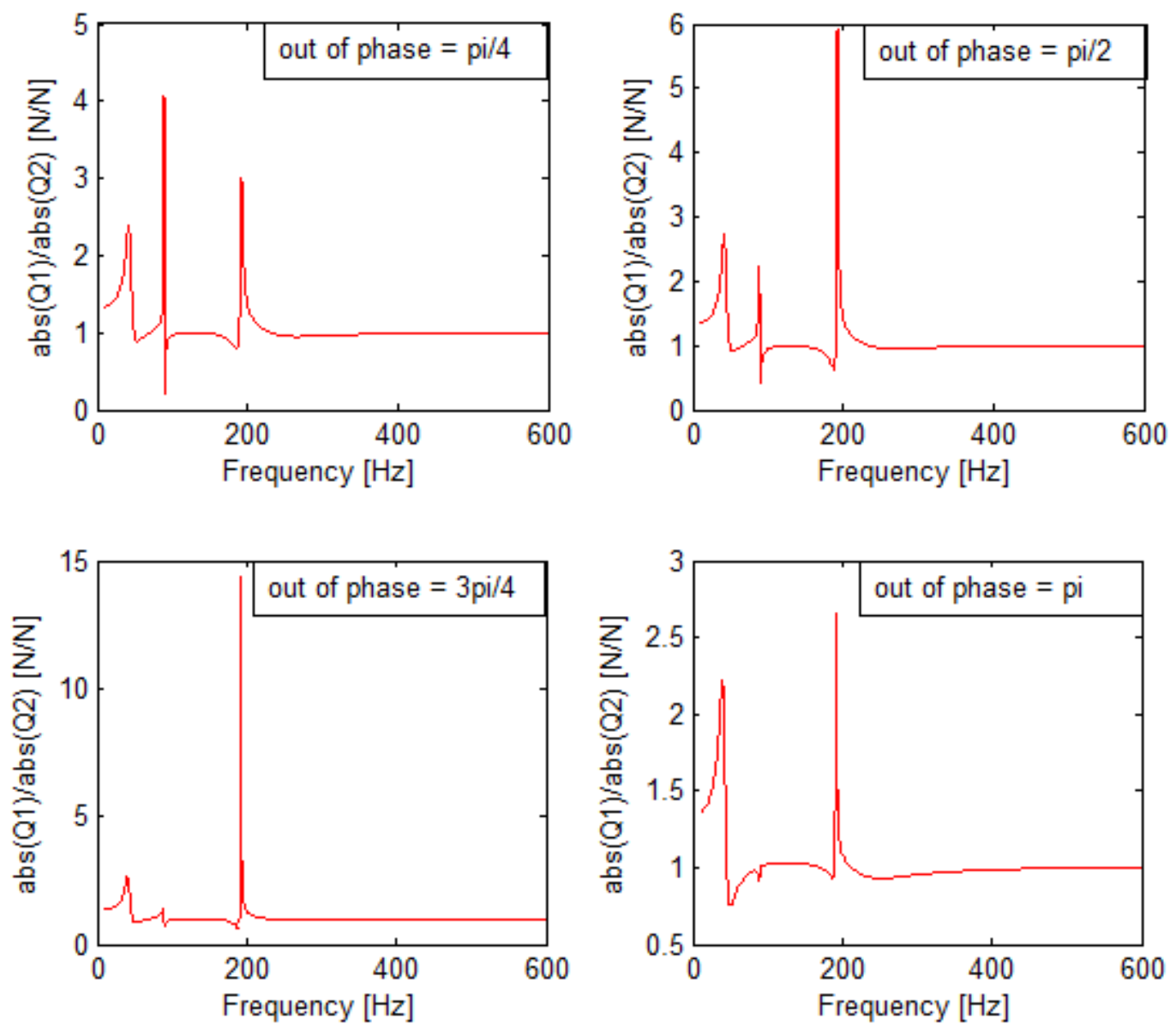

Figure 10. Contact forces ratio.

Overall, the FRF at the two wheels either in displacements or in contact forces are not equals because of the asymmetric inertia of the driving wheelset. It is interesting to evaluate the impact of the out of phase between the rolling surfaces irregularities on the FRF of the contact forces. Figure 10 shows the ratio between the contact forces (modulus) for four values of out of phase: $\pi / 4$, 
$\pi / 2,3 \pi / 4$ and $\pi$. The main differences between the two contact forces are located into the frequency range up to $200 \mathrm{~Hz}$, especially at the frequency of bounce-roll resonance of the driving wheelset/track system (about $42 \mathrm{~Hz}$ ) and at the wheelset resonances (about $89 \mathrm{~Hz}$ and $190 \mathrm{~Hz}$ ). At higher frequency, the impact of the out of phase between the rolling surfaces irregularities is very limited.

\section{CONCLUSIONS}

The driving wheelset has to support the weight of the locomotive, assuring the guidance in track. Representing the interface between locomotive and track, the driving wheelset plays the key role in traction and braking, which justifies the interest for its dynamics.

In this paper, the interaction between a driving wheelset and track has been investigated to point out the impact of the inertial asymmetry of the driving wheelset on the system response to harmonic irregularities of the rolling surfaces. The driving wheelset has been modelled using a finite length continuous-discrete model, representing the axle, wheels and gear, and the modal analysis method has been used to calculate the wheelset receptance at both wheels. The track was reduced to two independent infinite continuous beams on foundation with two elastic layers and an inertial one inserted between these.

The moving irregularity model was used to investigate the influence of the out of phase between the rolling surfaces irregularities upon the frequency response functions of the driving wheelset/track.

The driving wheelset/track system is a resonant one whose resonance frequencies are in the frequency range in which the rails develop evanescent waves. Numerical application revealed that in the considered case, there are three resonance frequencies. FRF of the driving wheelset/track are different from a wheel/rail pair to other one due to the inertial asymmetry of the wheelset even when the rolling surface irregularities are identic on both parts (left-right). Also, FRF present different values on left and right side due to the out of phase of the rolling surfaces irregularities. These asymmetries in FRF shape manifest at frequencies lower than the highest resonance frequency of the driving wheelset/track system and potentially influence all phenomena involving wheel/rail friction force. 


\section{ROMANIAN JOURNAL \\ OF TRANSPORT INFRASTRUCTURE}

Traian Mazilu, Ionuţ Radu Răcănel, Marius Alin Gheți,

Vertical interaction between a driving wheelset and track in the presence of the rolling surfaces harmonic irregularities

\section{Acknowledgments}

The activity of Marius Alin Gheți, $\mathrm{PhD}$ student, in this work has been funded by the European Social Fund from the Sectorial Operational Programme Human Capital 2014-2020, through the Financial Agreement with the title "Scholarships for entrepreneurial education among doctoral students and postdoctoral researchers (Be Entrepreneur!)", Contract no. 51680/09.07.2019 SMIS code: 124539.

\section{REFERENCES}

[1] X. CUI, G. CHEN, J. ZHAO, W. YAN, H. OUYANG, M. ZHU: "Field investigation and numerical study of the rail corrugation caused by frictional self-excited vibration", Wear 376-377, 2017, 1919-1929.

[2] T. X. MEI, J. H. YU, D. A. WILSON: “A mechatronic approach for anti-slip control in railway traction", Proceedings of the $17^{\text {th }}$ World Congress The International Federation of Automatic Control, 2008.

[3] M. DUMITRIU: "Influence of the longitudinal and lateral suspension damping on the vibration behaviour in the railway vehicles", Archive of Mechanical Engineering 62, 2015. 115-140.

[4] B. FU, S. BRUNI, S. LUO: "Study on wheel polygonization of a metro vehicle based on polygonal wear simulation”, Wear 438-439, 2019, Article 203071.

[5] Y. TIAN, S. LIU, W. J.T. DANIEL, P. A. MEEHAN: "Investigation of the impact of locomotive creep control on wear under changing contact conditions", Vehicle System Dynamics 53, 2015, 692-709.

[6] T. MAZILU, M. DUMITRIU: "On the steady state interaction between an asymmetric wheelset and track", Proceedings of the Thirteenth International Conference on Civil, Structural and Environmental Engineering Computing, 2011.

[7] S. L. GRASSIE, R. W. GREGORY, D. HARRISON, K. L. JOHNSON: "The dynamic response of railway track to high frequency vertical excitation", Journal Mechanical Engineering Science 24, 1982, 77-90. 